\title{
LA REPRESENTACIÓN ESTÉTICA DEL PAISAJE URBANO EN LA OBRA DEL ARQUITECTO RAFAEL "FELO" GARCÍA
}

\author{
The aesthetic representation of the urbanscape in the work of the architect Rafael "Felo" García
}

Rodolfo Mejías Cubero*

\begin{abstract}
RESUMEN
En la obra del arquitecto Rafael Felo García, vemos cómo el atractivo plástico del paisaje del tugurio se traduce en ropas tendidas, antenas, cables, tejados, ventanas, puertas, calles, aglomeraciones y demás efectos escenográficos del paisaje urbano, se convierten en el motivo de su composición plástica. Esta investigación busca documentar y analizar una pequeña muestra representativa de las obras de García entre 1957 y 2003 , como un medio a través del cual podemos identificar los elementos de la representación estética utilizada por el autor como representación pictórica de componentes, tanto del diseño arquitectónico como elementos del paisaje urbano representativos.

Palabras clave: Arte, Arquitectura, Fotografía, Paisaje urbano, Representación visual.
\end{abstract}

\begin{abstract}
In the work of architect Rafael Felo García, we see attractive landscape plastic the marginal house results in clothes hanging, antennas, cables, roofs, windows, doors, streets, crowds and other scenic effects cityscape becomes the reason for its plastic composition. This research aims to document and analyze a small sample of the works of García from 1957 at 2003, as a means through which we can identify the elements of aesthetic representation used by the author as a pictorial representation of both components as elements of architectural design representative urban landscape.
\end{abstract}

Key Words: Architecture, Art, Cityscape, Photography, Visual Representation.

Universidad de Costa Rica. Escuela de Arquitectura. Costa Rica.

Correo electrónico: mejiasarq@gmail.com

Recepción: 3/7/16. Aceptación: 24/4/17. 


\section{Introducción}

Al inicio de los años setenta, luego de muchos años éxitos como deportista (futbolista profesional), artista y arquitecto, Rafael Ángel García Picado, (Felo García) retoma el tema urbano del tugurio como estandarte de su obra. Sus representaciones plásticas trasmiten su percepción arquitectónica y urbana del paisaje. Su trabajo es visto por algunos como una búsqueda esteticista del tugurio $\mathrm{y}$, por otros, como una denuncia social ante la crisis demográfica urbana de la época.

"La estética de lo marginal" está presente en la obra del artista a través de abstracciones de la materialidad, la luz, la forma, los colores, las perspectivas, las texturas visuales y táctiles, las tramas, grillas y abstracciones geométricas de la realidad. En todo esto está ausente la figura humana, salvo la del espectador que interioriza la obra.

El argumento que se estudiará en este documento, tratará primero sobre una breve retrospectiva de la vida del arquitecto Rafael Felo García y sus inicios en la pintura abstracta. Posteriormente, se revisarán los principales postulados teóricos del movimiento artístico en el que se desarrolló el artista inicialmente. Luego, se expondrán los elementos representativos de la forma y el espacio arquitectónico y urbano que se buscará identificar y asociar a los elementos de representación estética utilizados por García. El enfoque metodológico de esta búsqueda de asociaciones del paisaje urbano en la obra plástica, se realizará mediante el análisis visual de veintiocho imágenes fotográficas seleccionadas de obras comprendidas entre el año 1957 y el 2003. Se buscará identificar diferentes formas de abordar el tema del paisaje urbano en función de la evolución estilística del autor en las obras analizadas. Los ficheros de las obras analizadas se adjuntan en el Anexo al final del documento.

\section{1. "Felo" García}

\subsection{Sus comienzos en el arte}

Rafael Ángel García Picado, (Felo García), nace en Paraíso de Cartago en el año 1928. Menor de siete hermanos de una familia humilde de agricultores, viviría su infancia en el contexto urbano de los años treinta en Barrio Aranjuez, San José. A sus 86 años, don Felo representa, además de la generación de precursores de la pintura abstracta en Costa Rica, a los precursores de la enseñanza de la arquitectura y el primer director de la Escuela de Arquitectura de la Universidad de Costa Rica en 1971:

De estudiante de arquitectura a futbolista. La urgencia de Rafael Ángel "Felo" García de seguir la carrera de arquitectura y la escasez de profesionales en dicho ramo en Costa Rica, le valieron que gobierno de su primo, el Presidente Teodorico Picado, le otorgara una beca de estudios. Fue así como en 1947 se encontró viajando hacia Londres para estudiar en el Hammersmith College of Building and Artes. Durante su estadia en Londres, tuvo su primer contacto con la pintura europea a través de galerías; su interés; sin embargo, se mantuvo concentrado en sus estudios de arquitectura. En realidad la beca le duró poco; se la suspendieron en el momento en que cursaba el segundo año, al estallar la Revolución del 48. Este cambio de circunstancias lo llevó, como dice el propio artista, a quedarse "por alli tirado por algún tiempo". Así fue como García llego a Cuba, en donde halló en el futbol profesional un modus vivendi. El artista permaneció alrededor de dos años en este país, desempeñándose en dicha ocupación (Zavaleta, 1994:7).

Una vez ubicado en Cuba, Felo García conoce a Manuel de la Cruz González Luján (1909-1986), artista que marcaría no solo la historia de la pintura en Costa Rica, sino que, además, el devenir artístico de García a través del expresionismo abstracto. En esa época, Manuel de la Cruz González se encontraba autoexiliado en Cuba y Venezuela. El expresionismo abstracto ofreció a Felo García la oportunidad de encontrarse con su sensibilidad creadora. Cita 
Zavaleta (1994:7) que "el entonces futbolista recuerda haber asistido a varias exposiciones de González y de haber "garabateando" de vez en cuando con su compatriota".

De esta época es también la conocida anécdota que cuenta cuando ambos acordaron que el primero en llegar a Costa Rica, "lo sacudiría todo”. Sin embargo, García todavía no pintaba; el futbol le consumía todo su tiempo. El pintor pasó de Cuba a Colombia para continuar jugando el mismo deporte. Es este lugar en donde comenzó a dibujar con mayor constancia, enfocó su tema de interés en los tugurios de los barrios bajos de Cali, Medellín y otras ciudades. Asimismo, visitó exposiciones en las que pudo apreciar la obra de artistas como Omar Rayo y Fernando Botero (Zavaleta, 1994:7).

\subsection{El expresionismo abstracto}

El arte abstracto nace en Europa con la obra de Vassily Kandinsky, quien en 1910, a los 44 años, pinta su primera obra abstracta $y$, paralelamente, como una forma de respaldo para esta forma de expresión, empieza la redacción de Lo espiritual en el arte, comunicación a la que le sucedieron otras en las que deja patente que su forma de expresión es producto de una convicción profunda. Por medio del análisis de la forma y el color, encuentra un camino que lo conduce a la abstracción, no como una forma de expresión espontánea, sino reflexiva. El arte abstracto evoluciona a través de los años a los que se adivinan diferentes corrientes: Dora Vallier, en su libro L'Art Abstrait, distingue diferentes periodos, el de 1910 a 1920 lo caracteriza por una extraordinaria vitalidad creadora. El de 1920 a 1930 es su fase experimental y el de la aplicación práctica de las formas abstractas en la arquitectura, muebles y artes gráficas; alrededor de 1930 sucede la expansión por toda Europa. En 1939 es cuando estalla la guerra y parece que pierde su fuerza creadora. Después de la guerra en 1945, se retoma con nuevo vigor y esta vez los Estados Unidos entran en escena y se universaliza (Alvarado, 2005: 32).

Felo García vive toda esta efervescencia artística en la década de sus veinte años. Como cita Alvarado (2005:30): "Inquieto y creativo se deja subyugar por esta forma de expresión, en la que, mediante un proceso mental, se separa la realidad del realismo y construye una nueva realidad. Adopta una forma diferente de comunicación, subjetiva al más alto nivel, cuya significación se sustenta en la lectura de formas, la combinación de colores y el contraste de texturas".

En 1952, el crítico Harold Rosenberg introduce el término "Action Painting" o "pintura gestual" para referirse a una de las modalidades del expresionismo abstracto. Este sería de los géneros pictóricos en los inicios de la carrera de García.

\subsection{Regreso a Costa Rica}

Para inicios de la década de los cincuenta, Felo García regresa a Costa Rica, donde comienza a laborar en el Ministerio de Obras Públicas y Transportes. En este trabajo conoce al arquitecto y pintor costarricense Teodorico Quirós (1897-1977), que se convertiría en su mentor. Zavaleta (1994:7), al respecto indica lo expresado por García en relación con la influencia de estos dos artistas: "Tal vez, don Quico... y un poco Manuel, pero yo diría que entre los dos, don Quico más me influenció para realmente dedicarme a pintar".

Junto a Quirós, trabajó mucho el paisaje rural, utilizando, sobre todo, la técnica de la acuarela y un poco el óleo y la mixta. Sin embargo, aquellos cuadros que estaba produciendo lo llevaron a cuestionarse cuál era la pintura que el más sentía. El paisaje le atraía, pero no le satisfacia del todo. Sabia que necesitaba algo más, que se identificara con sus propios sentimientos; en realidad, tenía el ímpetu de encontrar aquello que llenara sus expectativas en pintura, sin saber, tampoco, cuáles eran estas. Probablemente, este conflicto surgió cuando García enfrentó el punto de vista de los dos artistas que lo habian influido profundamente, pero que se contraponian rotundamente, o sea, el de González o el de Quirós. El problema se resolvió cuando regresó a Inglaterra en 1954 (Zavaleta, 1994:8).

Una vez estabilizado el panorama político de Costa Rica, luego de la Guerra Civil de 1948, y gracias al aporte de una nueva beca del 
Gobierno, García continúa sus estudios en el Hammersmith College of Building and Arts en Londres. Pero su regreso ahora estaba marcado por una nueva perspectiva del arte:

Su búsqueda concluyó al descubrir que los actores principales de la obra podían ser los elementos plásticos de la pintura -color, forma, línea, espacio, textura, movimiento- y no la realidad objetiva, consideración que en un medio como el costarricense hubiera sido muy difícil de estimar. Los cuadros en que se exponían los nuevos movimientos los estudió y los analizó -cómo estaban ejecutados, cómo eran sus trazos, qué instrumentos se habian utilizado-, procedimiento que lo fue conduciendo hacia la abstracción (Zavaleta, 1994:9).

En esta oportunidad y con otros estudiantes, incursiona en el mundo artístico con el Grupo Nueva Visión (1954). Ya graduado regresaría a Costa Rica, pero le esperaba un ambiente artístico muy diferente a lo vivido en Europa.

Zavaleta (1994:23) expresa que: “(...) el artista recuerda el arte costarricense de ese periodo así: "(...) era tan intransigente que el conformismo habría inundado todos los medios... los artistas andaban en pequeños grupos apoyándose unos a otros en su propia obra".

El medio artístico costarricense era inhóspito para las nuevas tendencias artísticas del arte. La segunda muestra de arte abstracto fue auspiciada por la Asociación Costarricense de Arquitectos en 1958. Zavaleta (1994:23) indica lo expresado por García: “(...) que la exposición causó un impacto espantoso, que las personas se reían de las obras, y concluyó que la gente nunca había visto tanta cantidad de cosas extrañas, manchas, líneas (...). Asimismo, surgió la burla, decían que no sabía dibujar, que le habían regado la pintura o que había brincado encima de las pinturas".

También cuenta la historia de una dama que al observar una de las obras expuestas manifestó: yo habia sentido jaquecas, pero esta es la primera vez que veo una (Alvarado, 2005: 32).
Recuerda este episodio a la famosa exposición de arte moderno organizada por Hitler en Múnich (1937), El arte degenerado, donde cita Toby Clark (2000: 63): “(...) exhibió más de 700 obras de arte moderno con el único propósito de burlarse de ellas y vilipendiarlas". Aunque se podría pensar que los comentarios expresados por el público costarricense de la época, más que obedecer a algún interés ideológico radical, corresponderían a un pensamiento conservador, fuertemente arraigado para entonces.

Así, Manuel de la Cruz Gonzales, Lola Fernández y Felo García, se consolidarían como los precursores de la pintura contemporánea en Costa Rica y, en especial, con la conformación del grupo de artistas que se denominaría el Grupo Ocho (1961).

\section{La imagen y el paisaje urbano}

Borges (1998: 251) decía "Los ojos ven lo que están habituados a ver". Sin embargo, la formación cultural del observador influye, por lo que, tanto el paisaje urbano como sus imágenes estarán definidos por la percepción individual. A través de la percepción particular de una situación, definimos las imágenes urbanas, que en su conjunto configuran el paisaje urbano. Por lo que el paisaje urbano está formado por diferentes zonas de imagen. Tenemos conciencia de las imágenes al movernos por ellas, es decir, vivimos el paisaje urbano solamente si recorremos la ciudad. Por ejemplo, una vista a la distancia de la ciudad solo nos ofrecería una condición del imaginario llamada silueta urbana y no el paisaje en su verdadera dimensión vivencial. El paisaje en su totalidad es dinámico, no una connotativa como la ofrecida en la imagen fotográfica de las postales turísticas. Barthes (1986:14) indica que: “(...) un sistema connotado está constituido visiblemente bien por un sistema de símbolos universal, bien por una retórica de una época, en definitiva, por una reserva de estereotipos (esquemas, colores, grafismos, gestos, expresiones, agrupaciones de elementos)". Por eso, las postales turísticas 
sobre paisajes de ciudades en diferentes países se parecen entre sí, porque buscan un lenguaje connotativo universal para ser interpretado por el turista, por procedimientos típicos de la connotación, como lo son el trucaje, la pose, los objetos y la fotogenia, entre otros aspectos citados por Roland Barthes.

\subsection{Conceptos}

Para definir cuáles elementos del paisaje se analizarán en la obra pictórica del artista, se hará referencia a la imagen urbana y sus relaciones con el paisaje urbano:

La imagen urbana es una percepción particular
de una situación especifica de la ciudad; en
consecuencia, el paisaje urbano es un resultado
directo de las imágenes urbanas, es más genérico y
global. El Paisaje Urbano es un concepto diferente
de la disciplina del Paisajismo. El Paisajismo se
diferencia del Paisaje Urbano en que brinda una
transformación o adecuación de la naturaleza
para el disfrute del ser humano; en consecuencia,
el Paisaje Urbano es un conjunto de imágenes de
un entorno construido o en donde se desarrollan
actividades humanas. La imagen urbana surge de
la síntesis realizada por los individuos mediante
procesos perceptuales, de las caracteristicas,
actos o condiciones del entorno temporal,
físico-geográfico y humano de la ciudad. Esta
construcción es elproducto de la recreación mental
de imágenes, asociaciones, recuerdos, elementos,
símbolos, conjuntos de formas, espacios, elementos
naturales y, sobre todo, las actividades humanas
del momento histórico en que se vive; en fin, todos
los estímulos que recibe el perceptor al recorrer la
ciudad (Mejías, 2013: 15).

Cuando un grupo cultural se adapta a un "lugar" de manera "armónica" crea vínculos con él. Esta adaptabilidad del individuo es percibida por la cultura que la propicia o bien desde el exterior por otro criterio de valores diferentes. Este proceso de interpretación del ordenamiento físico de las formas, los espacios y la conciencia de identidad cultural, es una práctica habitual en la arquitectura y el urbanismo. Por lo que el mismo don Felo indica en una entrevista, que su interés por el tugurio le viene de su formación como arquitecto. De ser así, la representación plástica del artista es el producto de la recreación mental de imágenes, asociaciones, recuerdos, elementos, símbolos, conjuntos de formas, espacios, elementos naturales $\mathrm{y}$, sobre todo, las actividades humanas que en algún momento García experimentó y, como tal, sintetizó en la abstracción de su obra:

(...) me llega primero por influencia de la visión profesional, la arquitectura y planificación. Eso yo creo que en definitiva tiene que haber contribuido, porque todo lo que se derivaba de la observación mía cotidiana, de la ciudad y en las ciudades, ese estado de alerta siempre por la cosa urbana, me llevó a definitivamente a plantear ese problema del tugurio, ya que el paisaje social es más importante que el paisaje de la casa bonita; la casa elegante, esa, no me da ningún mensaje; el otro, como es una cosa espontanea, con materiales encontrados al azar, me sugiere muchísimas más posibilidades plásticas y, además, me clarifica mucho la urgencia de espacios de evidencia; lo más interesante es que me llevó casi cuatro años resolver el problema, lograr la sintesis que estaba buscando y darme cuenta que no necesitaba poner gente. Para mi ha sido notable, un ejercicio muy importante, geométrico, porque hay una gran geometría en toda la pintura de tugurios, con las texturas extraordinarias que salen de ahi (Alvarado, 2005: 35).

\subsection{Variables por identificar}

\subsubsection{Elementos de imagen urbana}

Para enumeración de los elementos por identificar, se hará mención a las cuatro categorías de estudio de la imagen urbana (Mejías, 2013: 840), estas son:

Secuencias dinámicas del lugar: comprende el recorrido a través de los eventos y espacios de circulación dentro de la ciudad.

Construcción visual del lugar: esta abarca los aspectos formales que visualizamos cuando hacemos ese recorrido.

Sentido del lugar: este punto analiza los adjetivantes que le dan las cualidades propias a los espacios que estamos recorriendo. 
Evaluación del lugar: que corresponde al estudio de la calidad de dichas imágenes.

Sin embargo, para nuestros efectos la categoría que más se adapta a una lectura visual de una obra plástica es la "construcción visual del lugar". Ver cuadro 1.

\section{CUADRO 1}

Construcion visual del lugar

\begin{tabular}{ll}
\hline Cualidades de la forma & Singularidad \\
& Sencillez \\
& Continuidad \\
& Predominio \\
& Unión \\
& Diferenciación \\
\hline Morfología de la & Configuración \\
volumetría del lugar & Tamaño-densidad \\
& Trama-grano- textura \\
& Planta \\
& Silueta \\
\hline Componentes de la & Edificación representativa \\
arquitectura del lugar & por periodo histórico \\
& presente en el lugar \\
& Fachada: aberturas y \\
& techumbres \\
& Materiales y color \\
\hline
\end{tabular}

\section{Análisis de elementos representativos}

\subsection{Aspectos metodológicos para el análisis}

Las obras seleccionadas corresponden a una recopilación de los referentes bibliográficos de esta investigación, con ello se pretende configurar una muestra no exhaustiva de la vasta producción de García en torno del tema urbano. Esta muestra recoge veintiocho obras y bocetos, comprendida entre los años de 1956 al 2003.

Mediante la utilización de un tabulado de información, se identificarán puntualmente en cada obra los elementos representativos de la morfología urbana presentes y característicos de cada obra.

Se analizarán dichas características para evaluar la pertinencia de estas en las obras estudiadas como variables iconológicas e iconológicas comunes representativas.

Se omite en el estudio de las obras, ejemplos representativos de los años sesenta por no contar al momento del estudio con obras representativas de este periodo.

\section{Conclusiones}

“(...) El hecho de que podamos definir a un dibujo como una ficción, una mentira, un engaño, una ilusión, o un simulacro, tiene su importancia. Ya que de ello podemos extraer una importante paradoja enunciada por el profesor Ernst Gombrich: que un dibujo se parece a la realidad, aunque la realidad nunca se parece a un dibujo" (Montes, 1995: 864). Así en la "estética del tugurio" encontramos referentes al contexto social en que se desarrolló Felo García, donde sus obras son una aproximación estética a la realidad social de los años setentas. No obstante, este trabajo no pretende ser un análisis artístico exhaustivo de la obra de Felo García; su objetivo se centra en la búsqueda de asociaciones formales de las imágenes urbanas del paisaje en la temática del tugurio, presente en una selección representativa de sus obras. De los hallazgos encontrados tenemos que:

- Sus representaciones abstractas de los primeros años (década de los cincuenta) dan indicios de las primeras aproximaciones al tema urbano en sus obras. En estas composiciones él encuentra la génesis de un paisaje urbano de Felo García.

- Se evidencia en las obras analizadas, claras representaciones a siluetas urbanas representadas a través del expresionismo. En esta revisión se omiten (por no contar con imágenes) las obras representativas de la década de los sesenta. En los años setenta, García brinda un resurgimiento de la temática del tugurio: "Podemos decir que el año en que se abre la Escuela de Arquitectura con Felo García a la cabeza, se inicia el planteamiento de esta 
temática, que el artista venía elaborando desde hace mucho tiempo (...)" (Alvarado, 2005: 26).

- En la década de los setenta, y quizás con mayor influencia de la academia, el tema del tugurio explota en texturas y gamas cromáticas reducidas, hay mayor predominio de la masa edificada y la configuración es de perspectivas forzadas bajo los puentes o laderas. Hay un mayor contraste entre la figura y el fondo de las siluetas, lo cual evidencia un distanciamiento del expresionismo abstracto de los primeros años y define un estilo propio, García encuentra en la realidad urbana de la Costa Rica de los años setenta la materia prima para sus propuestas plásticas.

- En las obras analizadas de finales de la década de los ochenta y los años noventa, se nota un giro en lo que venía desarrollando, ya que encontramos, desde el punto de vista de la imagen urbana, una mayor predilección por el trazo libre, texturas más gruesas; continúa con el tema de la perspectiva forzada y la topografía es sustituida por manchas, y el color domina la composición a diferencia de los años setenta. Hay una mayor expresividad figurativa de la materialidad constructiva. Los colores evocan las cubiertas, las telas, puertas y sombras del interior de los aposentos. La cubierta oxidada se presenta en contraste con la pureza del color blanco de las telas lavadas y tendidas al sol.

- A finales de los noventa y primeros años del siglo XXI, García recrea paisajes escenográficos de gran formato (dípticos). Hay predilección por exploraciones geométricas en contraste con la fuerza expresiva de los trazos y las manchas de color.

Como cierre de este trabajo surgieron algunas interrogantes que el propio don Felo respondió:

\begin{abstract}
¿Cómo construye su lenguaje abstracto?
"Uno de los elementos más importantes para mí es la línea. La línea es la base de todo. Ahi es donde viene el trabajo que uno ejecuta por medio de la linea y que va dando tramas. Lo abstracto casi es inexplicable; gente lo ha manejado como matemática, como geométrica, lo que es el lenguaje abstracto. Para mi lo fundamental y esencial es la línea. Manejar la línea. Como un lenguaje que te va guiando solo; vos de repente hacés asi (dibuja una línea) y no sabés por qué, entonces, esa cosa se vuelve totalmente insustancial. Y te va llevando a tramas que son un encuentro extraordinario, que lo vas sintiendo y lo vas viviendo, básicamente, y no podés equivocarte, es un encuentro de lineas que pueden venir provocadas por el color, la luz, en fin; pero, básicamente, todo parte de la misma línea. La línea en sí te va demarcando un espacio, que puede ser un espacio externo, interno, eso solo lo puedes manejar vos mentalmente. Porque uno puede cerrar un espacio con solo dos líneas" ( $R$. García, Comunicación personal, 2014, julio 31).
\end{abstract}

¿Trabaja sus paisajes a partir de imágenes mentales (memoria), fotografías o visitas al sitio?

"Todo esto es vivencial partamos de eso. Se basa en la experiencia visual que uno ha tenido. Esto yo no lo puedo repetir; yo no puedo repetir nada de esto, si yo quisiera repetir un cuadro de estos no puedo, son irrepetibles, son vivencias. Que te digo, gran parte de la obra mía es de experiencias vivenciales" (R. García, Comunicación personal, 2014, julio 31).

¿Son metaimágenes las obras de don Felo García? Se puede concluir que sí. Según Mitchell (2009:57): "Cualquier imagen que se utilice para reflexionar sobre la naturaleza de las imágenes es una metaimágen". Su principal característica es explicar una búsqueda del autoconocimiento, así, a través del esteticismo de la patología urbana del tugurio se consigue reflexionar y profundizar sobre este tema.

\section{Referencias}

Alvarado, Ileana. 2005. Felo García, artista gestor, provocador, innovador. San José: Editorial Universidad de Costa Rica.

Barthes, Roland. 1986. El mensaje fotográfico. En: Lo obvio y lo obtuso. Barcelona: Editorial Paidós. 
Borges, Jorge Luis. 1998. El pudor de la historia. En: Otras Inquisiciones. Barcelona.

Castro, Abel; Monge, Luis; Pérez, Gustavo. 2009. Felo, Monografía. San José: GN.S.A

Clark, Toby. 2000. (secciones). Arte y propaganda en el siglo XX. La imagen política en la era de la cultura de masas. Madrid: Akal.

Mejías, Rodolfo. 2013. ¿Quién construye nuestro imaginario urbano? En: On the W@terfront. Barcelona: Universidad de Barcelona.
Mitchell, W.J.T. 2009. Metaimágenes. Teoría de la imagen. Madrid: Akal,

Montes, Carlos. 1995. Representación: el arte de decir mentiras en Il disegno luogo della memoria, Florencia: Alinea Editrice,

Zavaleta, Eugenia. 1994. Los Orígenes del arte abstracto en Costa Rica 1958 -1971. San José: Museo de Arte costarricense. 
6. Anexo: Tablas de análisis de las obras pictóricas.

\begin{tabular}{|c|c|c|c|}
\hline \multicolumn{2}{|c|}{ Datos de la obra } & \multirow[t]{2}{*}{$\begin{array}{l}\text { Componentes de la construcción visual de la } \\
\text { imagen urbana }\end{array}$} & \multirow[t]{2}{*}{ Imagen } \\
\hline Аก๊๐ & Descripción & & \\
\hline 2964 & 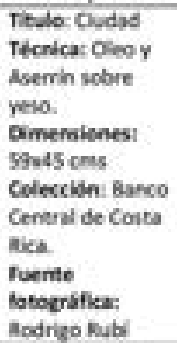 & 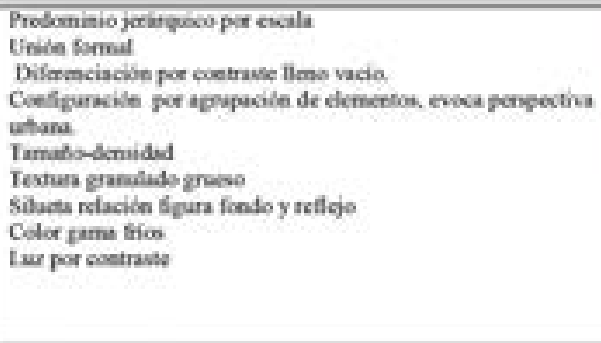 & 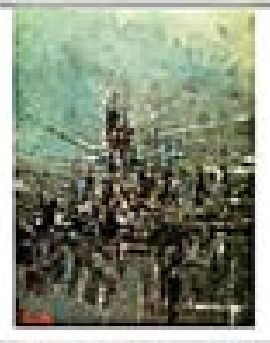 \\
\hline 1957 & 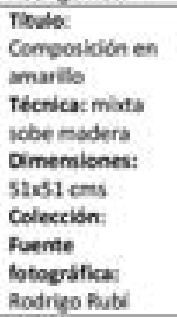 & 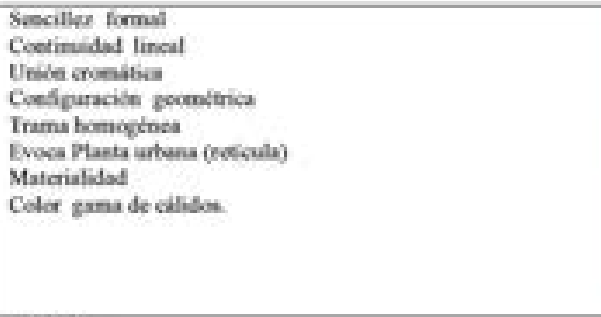 & 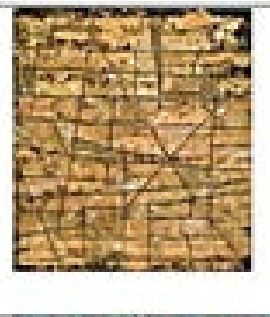 \\
\hline 1957 & 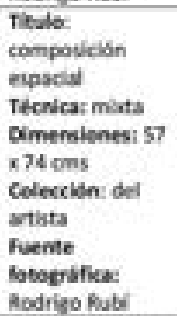 & 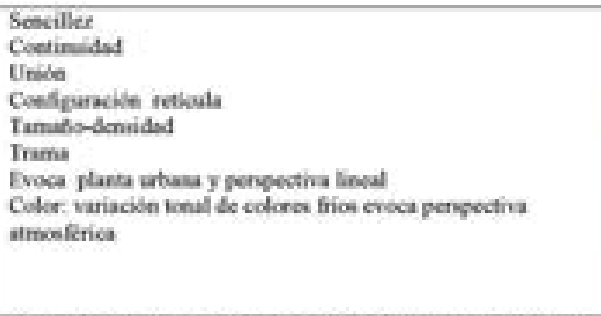 & $\frac{1+1}{4+12}$ \\
\hline 1957 & 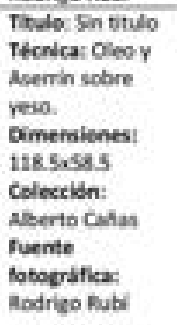 & 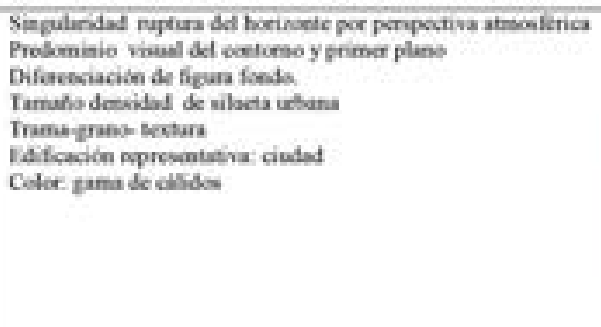 & \\
\hline
\end{tabular}




\begin{tabular}{|c|c|c|c|}
\hline \multicolumn{2}{|c|}{$\begin{array}{l}\text { Datos de la } \\
\text { obra }\end{array}$} & \multirow[t]{2}{*}{$\begin{array}{l}\text { Componentes de la construcción visual de la } \\
\text { imagen }\end{array}$} & \multirow[t]{2}{*}{ Imagen } \\
\hline Aติ๊o & Descripción & & \\
\hline 1968 & 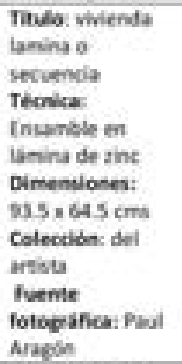 & 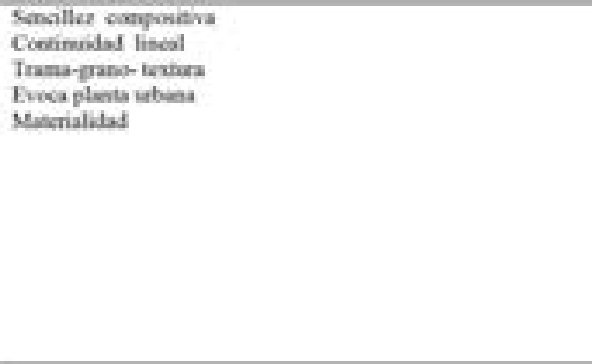 & 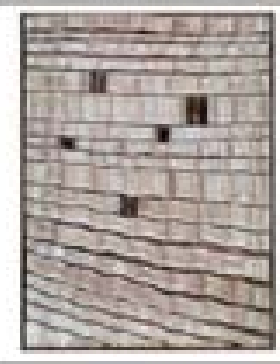 \\
\hline 1950 & 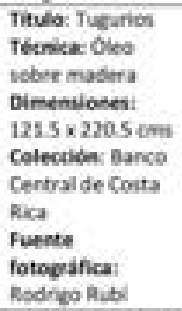 & 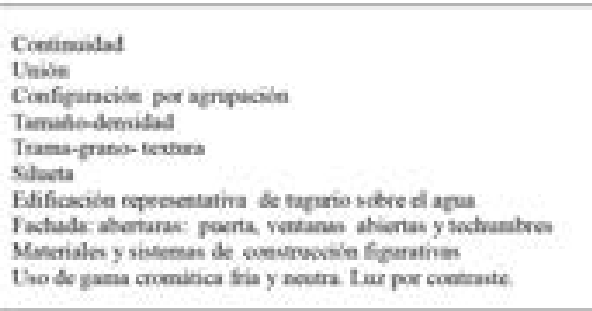 & \\
\hline $19 n$ & 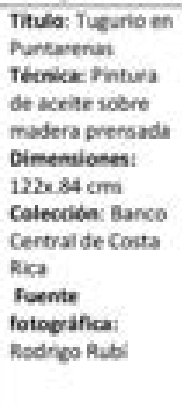 & 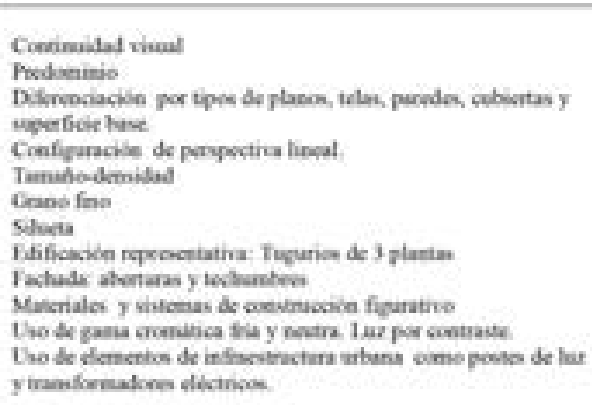 & \\
\hline 1973 & 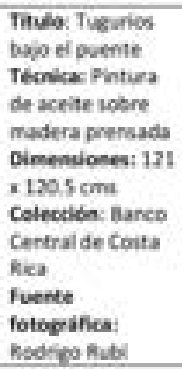 & 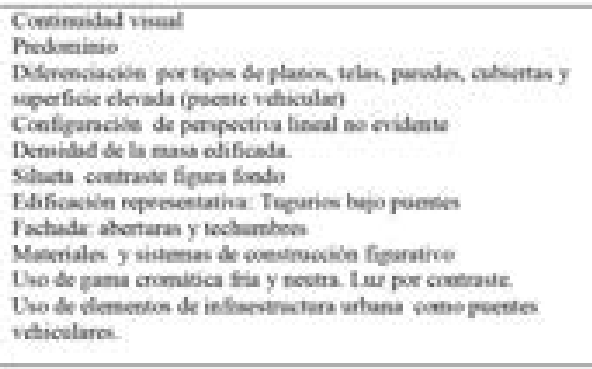 & \\
\hline
\end{tabular}




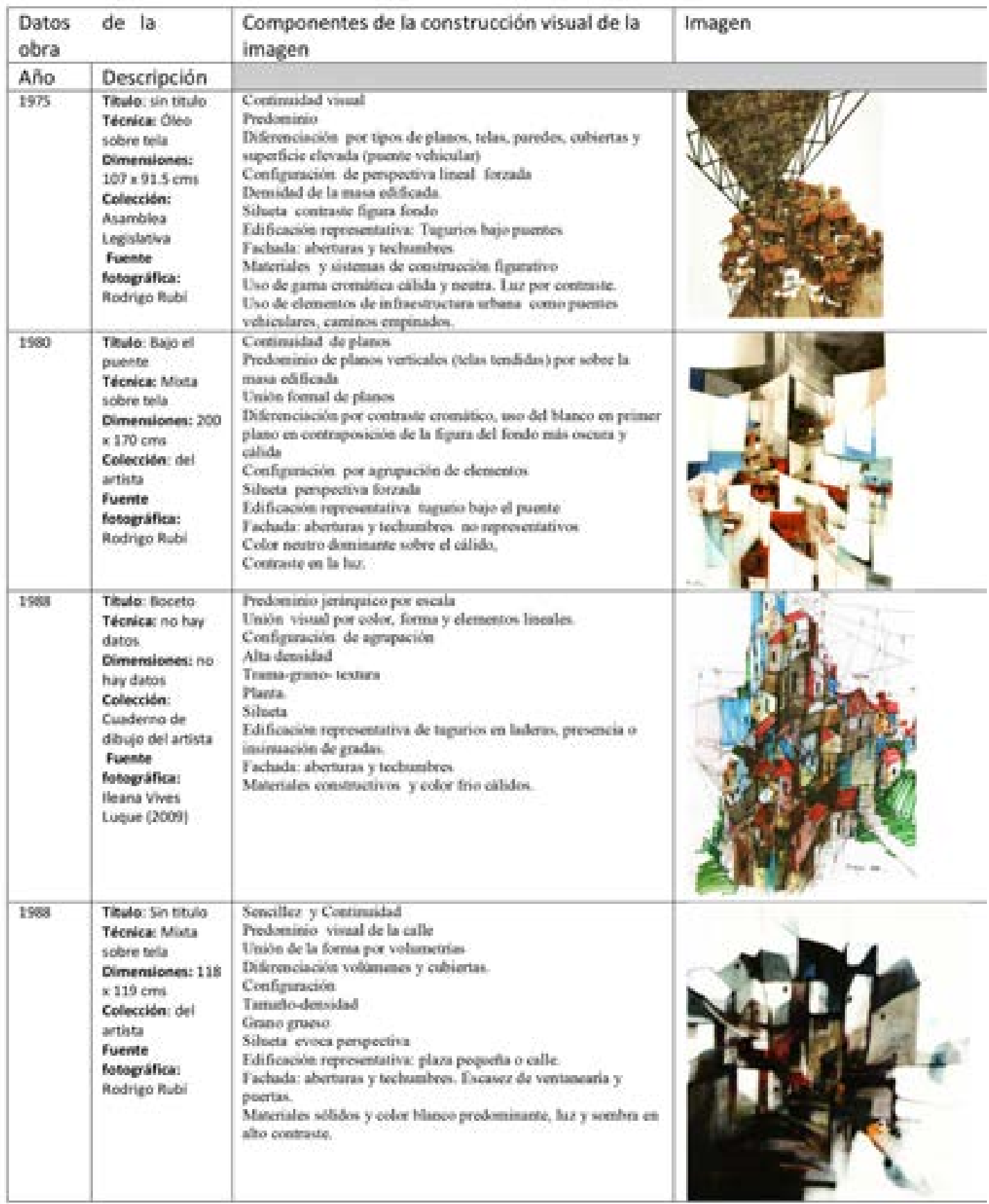




\begin{tabular}{|c|c|c|c|}
\hline \multicolumn{2}{|c|}{$\begin{array}{l}\text { Datos de la } \\
\text { obra }\end{array}$} & \multirow[t]{2}{*}{$\begin{array}{l}\text { Componentes de la construcción visual de la } \\
\text { imagen }\end{array}$} & \multirow[t]{2}{*}{ imagen } \\
\hline Aศ̆ం & Descripción & & \\
\hline 1990 & 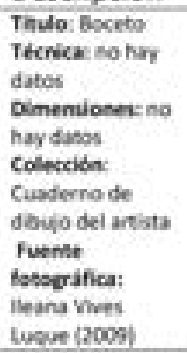 & 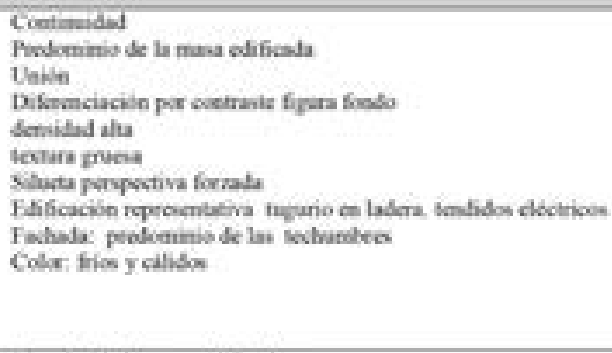 & \\
\hline 1901 & 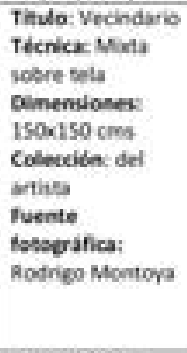 & 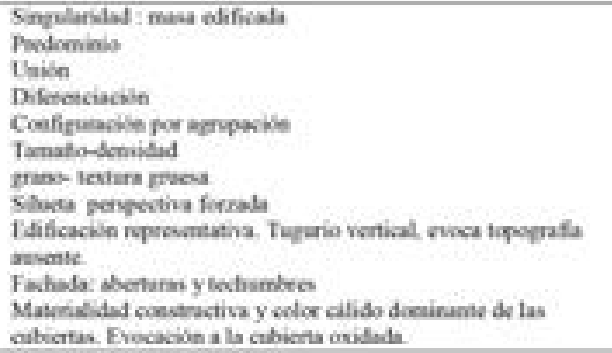 & \\
\hline 5991 & 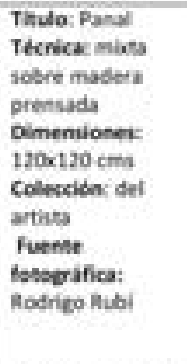 & 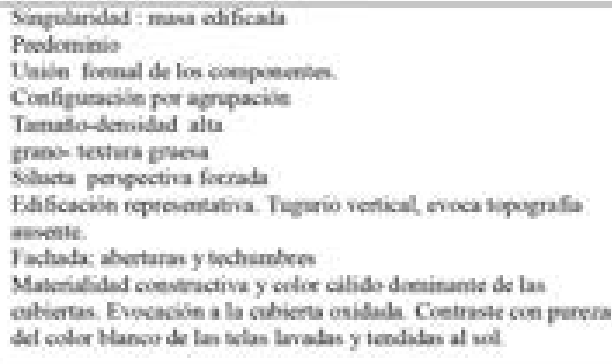 & \\
\hline 1922 & 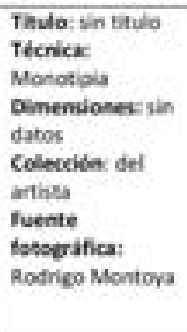 & 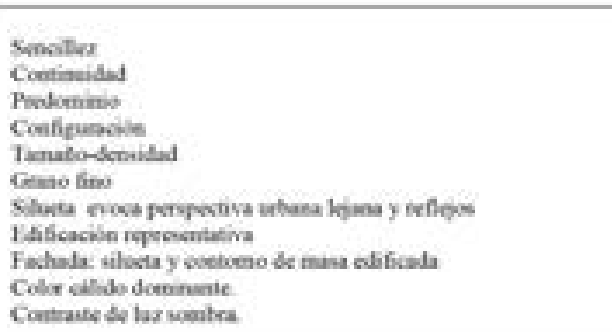 & \\
\hline
\end{tabular}




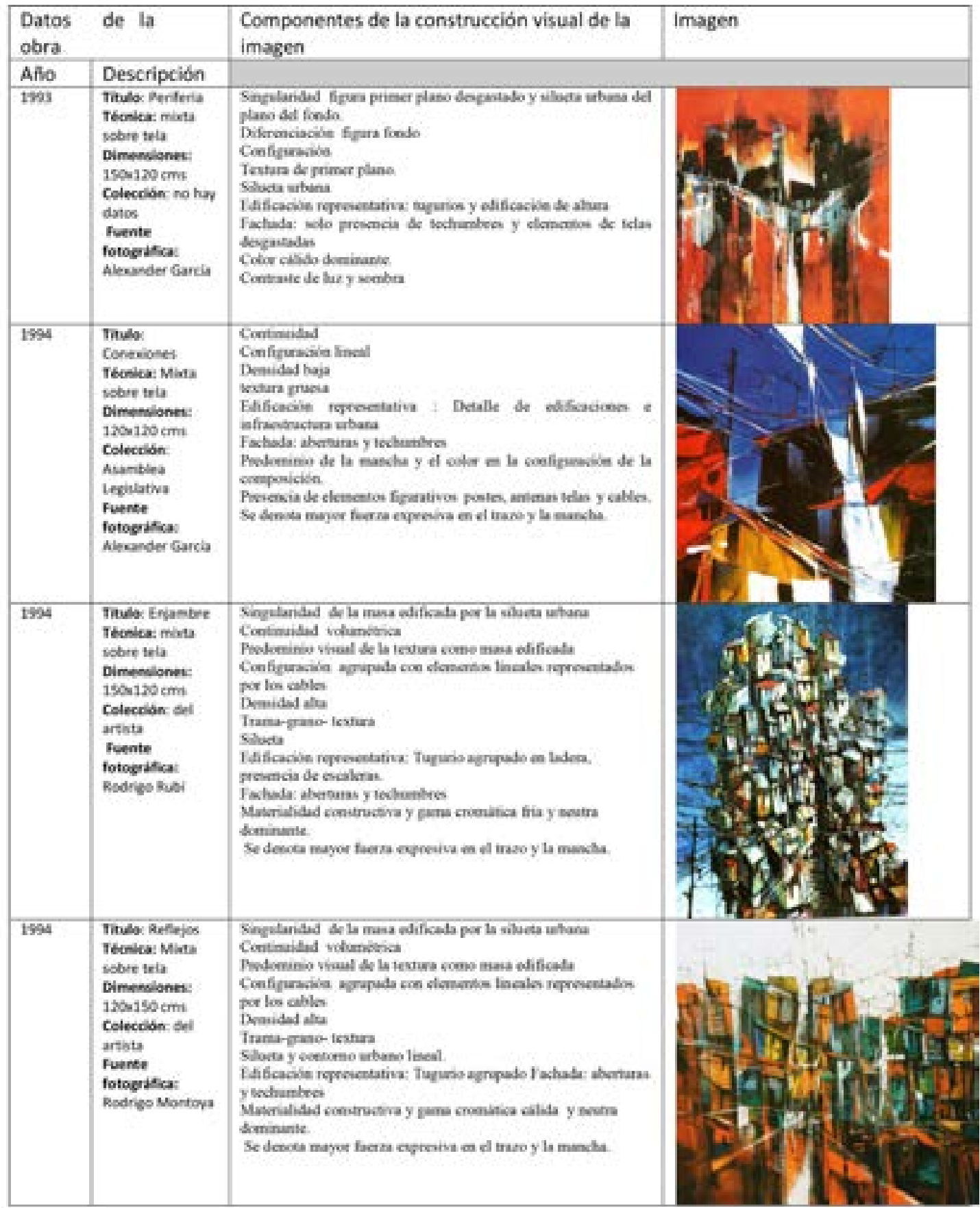




\begin{tabular}{|c|c|c|c|}
\hline \multicolumn{2}{|c|}{$\begin{array}{l}\text { Datos de la } \\
\text { obra }\end{array}$} & \multirow[t]{2}{*}{$\begin{array}{l}\text { Componentes de la construcción visual de la } \\
\text { imagen }\end{array}$} & \multirow[t]{2}{*}{ Imagen } \\
\hline Año & Descripción & & \\
\hline 1994 & 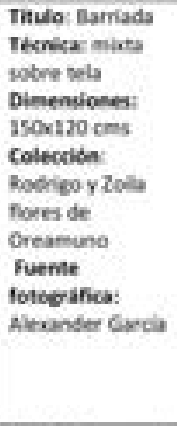 & 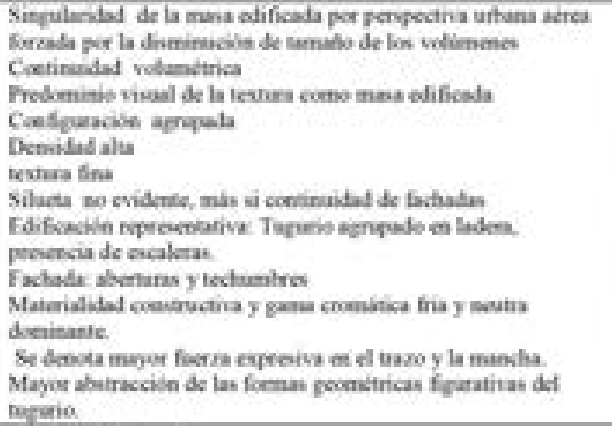 & \\
\hline 1956 & 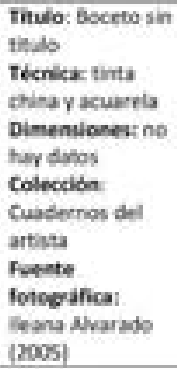 & 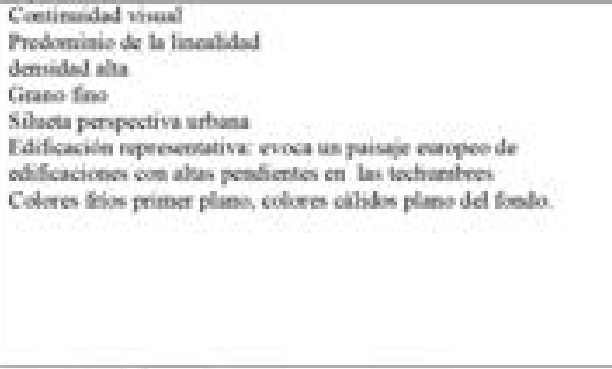 & \\
\hline 137 & 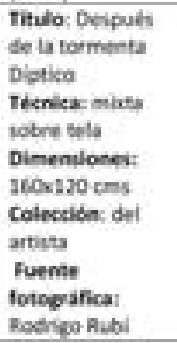 & 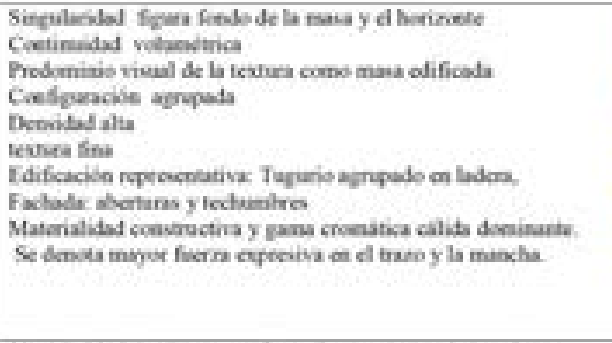 & \\
\hline 1398 & 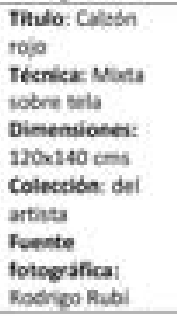 & 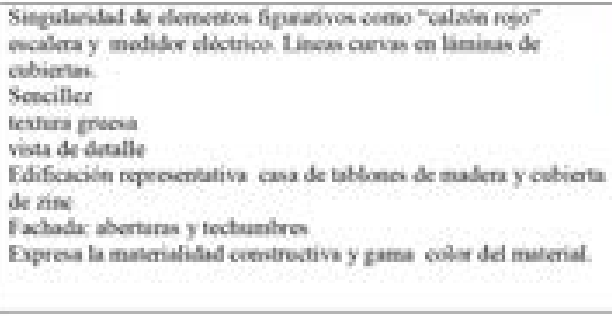 & \\
\hline
\end{tabular}




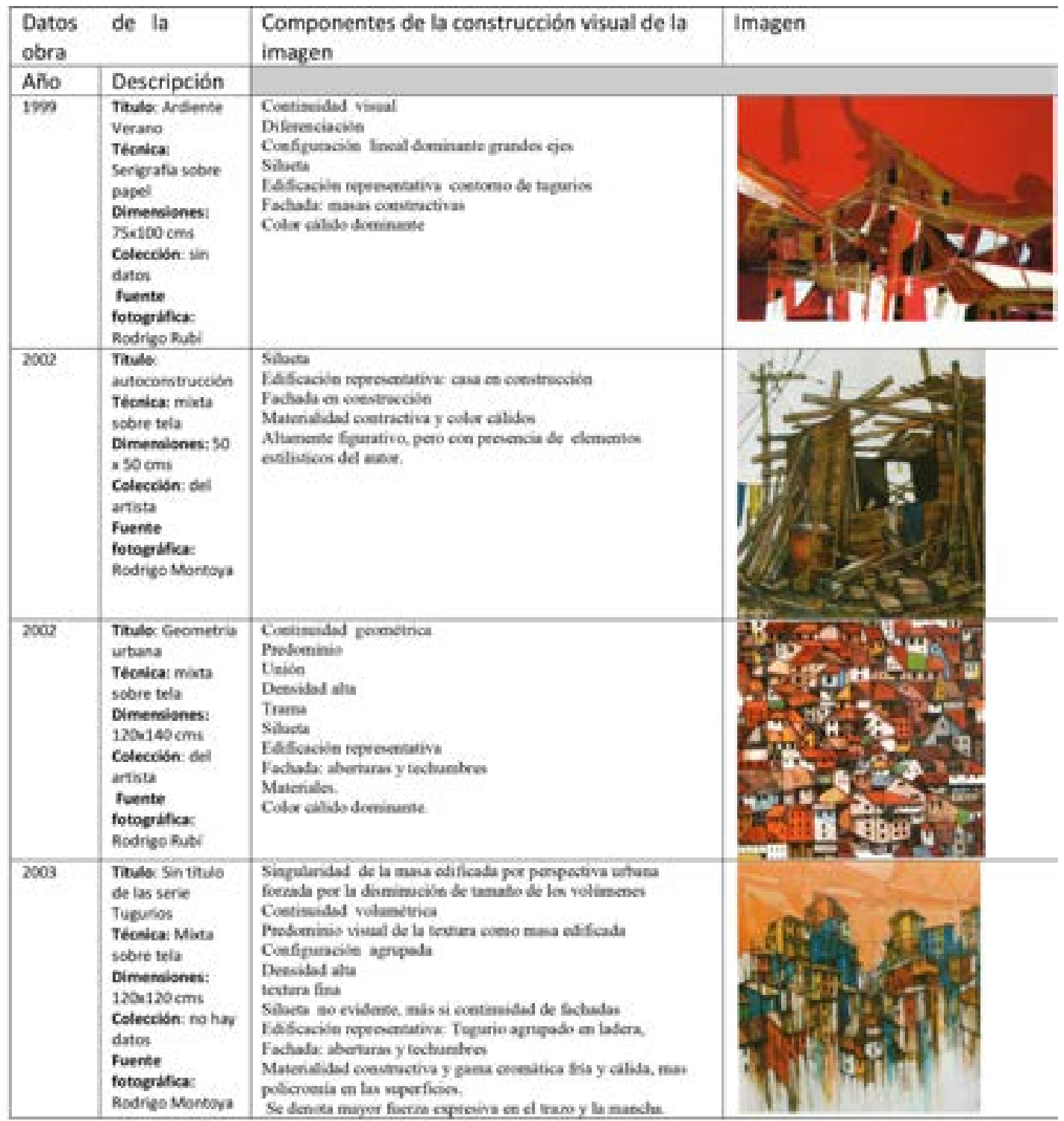

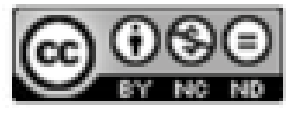

Este obra está bajo una licencia de Creative Commons

Reconocimiento-NoComercial-SinObraDerivada 4.0 Internacional. 